\title{
METODE PENYELESAIAN KASUS KREDIT BERMASALAH \\ DI LUAR PENGADILAN \\ (Studi Kasus PT. BPR Weleri Makmur Cabang Kudus)
}

\author{
Agus Istiqlal, Suparnyo dan Suciningtyas
}

Universitas Muria Kudus

Email : agus.istiqlal@yahoo.com,suparnyo@umk.ac.id, suciningtyas@umk.ac.id

\begin{abstract}
ABSTRAK
Kredit macet masih menjadi permasalahan pokok yang sering terjadi saat seseorang mengajukan hutang ke lembaga perkreditan, salah satunya perbankan. Cara menyelesaikan kredit macet yang dilakukan perbankan masih banyak menggunakan cara litigasi. Hal ini tentu tidak menghasilkan win-win solution antara kedua pihak, kecuali sebagai langkah terakhir. Maka dari itu diperlukan langkah penyelesaian secara non litigasi agar tercapai solusi yang adil dan tidak menghabiskan biaya dan waktu yang lebih lama.Tujuan penelitian ini untuk menilai Non Performance Loanyang cenderung naik dan menganalisis kebijakan PT. BPR Weleri Makmur Cabang Kudus dalam penyelesaian kasus kredit bermasalah di luar Pengadilan secara non litigasi dengan cara 3Ryaitu Rescheduling, ReconditioningdanRestructuring.Metode penelitian ini yaitu pendekatan yuridis empiris, sedangkan metode analisis yang digunakan adalah analisis kualitatif.Hasil penelitian ini memperlihatkan bahwa faktor penyebab terjadinya kredit bermasalah di PT. BPR Weleri Makmur Cabang Kudus yaitu faktor Internal Bank, anatara lain adanya tindakan fraud oleh karyawan, pelanggaran prinsip kehati-hatian dalam pemberian kredit oleh karyawandan faktor Ekternal Bank yaitu kondisi perekonomian dan kebijakan politik yang sering berubah, adanya bencana alam, serta adanya faktor debitor seperti iktikad kurang baik dari debitor, penyimpangan dalam penggunaan dana kredit, pola hidup yang boros dan mewah serta kegagalan usaha debitor.Penyelesaian kredit bermasalah di luar pengadilan dijadikan alternatif yang lebih diutamakan di BPR WM karena adanya masalah biaya, hasil yang dicapai, iktikad baik debitor dan kemampuan membayar.
\end{abstract}

Kata Kunci: NPL, Rescheduling, Reconditioning, Restructuring

PENDAHULUAN

Seiring dengan kemajuan dan perkembangan ekonomi dewasa ini dan juga semakin ketatnya persaingan yang terjadi dalam dunia usaha oleh para pelaku ekonomi, pelaku ekonomi dituntut untuk melakukan terobosan baru berupa inovasi perubahan ataupun perluasan produk yang tentunya memerlukan modal kerja agar tetap berkiprah dalam perkembangan dan kemajuan usahanya. Dalam hal ini, negara maupun pelaku ekonomi memerlukan $\begin{array}{llr}\text { institusi } & \text { pembiayaan } & \text { darilembaga } \\ \text { perbankan } & \text { atau lembaga } & \text { keuangan } \\ \text { lainnya. } & & \end{array}$

Pengertian mengenai perbankan dapat ditemukan dalam Pasal 1 angka 1 Undang-Undang Nomor 10 tahun 1998 tentang Perubahan Atas Undang-Undang Nomor 7 tahun 1992 tentang Perbankan (selanjutnya ditulis Undang-Undang Perbankan) sebagai berikut:"Perbankan

\footnotetext{
${ }^{1}$ Safir Senduk, " Prospek Perbankan di Indonesia", www.kompasroom.com, April 2014.
} 
adalah segala sesuatu yang menyangkut tentang Bank, mencakup kelembagaan, kegiatan usaha, serta cara dan proses dalam melaksanakan kegiatan usahanya". Dalam rangka memasuki era globalisasi dan menghadapi perekonomian nasional yang senantiasa bergerak cepat, sektor perbankan merupakan salah satu sektor yang harus dikembangkan dan dimanfaatkan secaramaksimal dalam pelaksanaan pembangunan ini demi mewujudkan pemerataan pendapatan masyarakat, terutama melalui fasilitas kredit yang diberikan oleh pihak perbankan bagi masyarakat.

Dalam kehidupan sehari-hari, kata kredit bukan merupakan perkataan asing bagi masyarakat kita. Perkataan kredit tidak saja dikenal oleh masyarakat di kotakota besar, tetapi sampai di desa-desa pun kata kredit tersebut sudah sangat dikenal. Istilah kredit berasal dari bahasa Yunani (credere) yang berarti kepercayaan (trust atau faith), sehingga itu dasar dari kredit adalah kepercayaan ${ }^{2}$.

Kredit yang diberikan kepada masyarakat tidak semua menjadi kredit yang sehat akan tetapi terdapat kredit yang bermasalah sehingga pihak Bank harus mengantisipasi terhadap indikasi kredit yang bermasalah dengan mengetahui penyebab serta cara menyelesaiakan kredit bermasalah tersebut melalui cara litigasi maupun dengan cara non litigasi.

PT. Bank Perkreditan Rakyat Weleri Makmur Cabang Kudus (selanjutnya ditulis BPR WM) merupakan salah satu Bank yang pernah menghadapi kredit bermasalah. Kredit bermasalah yang terjadi dikarenakan debitor kesulitan dalam pengembalian pinjaman sehingga

\footnotetext{
${ }^{2}$ Kasmir, "Bank dan Lembaga Keuangan Lainya", Edisi Revisi, PT. Rajagrafindo Persada, 2000, hlm.1.
}

menyebabkan kredit bermasalah yang dialami kreditor terus meningkat. Rasio NPLdikategorikan tidak aman jika berpedoman pada Peratuaran Bank Indonesia (PBI No.17/II/2015 tanggal 25 Juni 2015 Tentang Perubahan Atas Peraturan Bank Indonesia Nomor 15/15/PBI/2013) rasio NPL kredit Bank $5 \%$. Salah satu kunci untuk menilai kinerja bank adalah dengan menghitung rasio Non PerformingLoan (NPL).

Non Performing Loan merupakan indikasi adanya masalah dalam Bank tersebut yang apabila tidak segera mendapatkan solusi akan berdampak negatif bagi Bank. Dampak negatif tersebut salah satunya adalah mengurangi jumlah modal yang dimiliki oleh bank. Rumus perhitungan NPL adalah sebagai berikut:

Rasio $\quad \mathrm{NPL}=\frac{\mathrm{kol} 2+\mathrm{kol} 3+\mathrm{kol} 4}{\text { total kredit yang diberikan }} \mathrm{x}$ $100 \%$.

Penelitian yang dilakukan pada BPR WM tidak hanya sebatas nilai $N P L$ yang cenderung naik tetapi juga meneliti pada proses penyelesaian yang dilakukan secara non litigasi yang mana proses tersebut mempunyai kendala yang ditemui saat proses maupun pelaksanaan serta kesadaran dari pihak debitor dalam mencari win-winsoluiton.Proses penyelesaian non litigasi yang dilakukan BPR WM sesuai dengan Undang-Undang No. 30 Tahun 1999 tentang penyelesaian sengketa dalam bentuk penyelamatan nasabah kredit bermasalah dengan melalui cara $3 R \quad$ (Rescheduling, ReconditioningdanRestructuring) dalam pelaksanaannya belum bisa mengurangi jumlah kredit yang bermasalah.

Berdasarkan uraian latar belakang di atas, maka ada permasalahan yang akan dibahas yang dirumuskan sebagai berikut: 
1. Mengapa terjadi kredit bermasalah di PT. BPR WM?

2. Mengapa permasalahan tersebut menyebabkan kredit bermasalah di PT. BPR WM?

3. Mengapa penyelesaian kredit bermasalah di luar pengadilan dijadikan alternatif yang lebih diutamakan di PT. BPR WM?

\section{METODE PENELITIAN}

Metode pendekatan yang digunakan dalam penelitian ini adalah pendekatan yuridis empiris. Maksud penggunaan metode pendekatan yuridis empiris dalam penelitian ini adalah di samping menjawab permasalahan yang diteliti lebih ditekankan pada hasil penelitian lapangan, juga mendasarkan pada aspek yuridis. Aspek yuridis dalam penelitian ini adalah semua peraturan perundang-undangan yang berkaitan dengan kredit bermasalah ditinjau dari hukum perjanjian kredit. Adapun aspek empirisnya adalah penyelesaian kasus kredit bermasalah di luar pengadilan.

Spesifikasi penelitian ini adalah deskriptif analitis dan bersifat kualitatif. Penelitian deskriptif adalah penelitian yang bertujuan untuk memberikan gambaran seteliti mungkin mengenai manusia, keadaan dan gejala lainnya, atau penelitian untuk memecahkan masalah yang ada pada masa sekarang (masalah aktual) dengan mengumpulkan data, menyusun, mengklarifikasikan, menganalisis dan menginterpretasikan.

\section{HASIL PENELITIAN DAN PEMBAHASAN}

Menurut OP. Simonangkir dalam Budi Untung, ${ }^{3}$ kredit adalah pemberian prestasi (misalnya uang, barang) dengan balas prestasi (konstraprestasi) yang akan terjadi pada waktu yang akan datang. Kehidupan ekonomi modern adalah prestasi uang, yang dengan demikian transaksi kredit menyangkut uang sebagai alat kredit. Kredit berfungsi kooperatif antara si pembeli kredit dan si penerima kredit atau antara kreditor dengan debitor. Mereka menarik keuntungan dan saling menanggung risiko. Singkatnya, kredit dalam arti luas didasarkan atas komponen kepercayaan, risiko dan pertukaran ekonomi di masa-masa mendatang.

Menurut Thomas Suyatno ${ }^{4}$, perkreditan mengandung unsur-unsur kepercayaan, waktu, degree of risk, dan prestasi yaitu:

a. Kepercayaan, yaitu keyakinan dari si pemberi kredit bahwa prestasi yang diberikannya baik dalam bentuk uang, barang, atau jasa, akan benar-benar diterimanya kembali dalam jangka waku tertentu di masa yang akan datang.

b. Waktu, yaitu suatu masa yang memisahkan antara pemberian prestasi dengan kontraprestasi yang akan diterima pada masa yang akan datang

c. Degree of risk, yaitu suatu tingkat risiko yang akan dihadapi sebagai akibat dari adanya jangka waktu yang memisahkan antara pemberian prestasi dengan kontrapresti yang akan diterima dikemudian hari.

3 H.Budi Untung," Kredit Perbankan di Indonesia", Andi Offset, Yogyakarta, 2000, hlm.12.

${ }^{4}$ Thomas Suyatno, dkk, "Kelembagaan Perbankan", Gramedia, Jakarta, 1997, hlm.70. 
d. Prestasi atau objek kredit, prestasi tidak saja diberikan dalam bentuk uang, tetapi juga dapat bentuk barang atau jasa.

Kredit yang diberikan kepada debitor mendapatkan pengembalian kewajiban yang dilakukan debitor disebut dengan prestasi akan tetapi debitor yang tidak melakukan pengembalian kewajiban kepada kreditor disebut wanprestasi. Wanprestasi yang dilakukan debitor menyebabkan kredit yang diberikan menjadi bermasalah.

Kredit dikatakan bermasalah sejak tidak ditepatinya atau tidak dipenuhinya ketentuan yang tercantum dalam perjanjian kredit, yaitu apabila debitor selama tiga kali berturut-turut tidak membayar angsuran dan bunganya.

Tanda-tanda suatu kredit bermasalah adalah sebagai berikut:

a. Sebelum jatuh tempo, rekening tidak menunjukkan mutasi debet dan kredit;

b. Kredit mengalami overdraft secara terus menerus;

c. Adanya tanda-tanda bahwa debitor tidak sanggup lagi membayar bunga atas kredit yang diberikan pihak kreditor.

Menurut S. Mantayborbir, et.all, suatu kredit dikatakan bermasalah karena debitor wanprestasi atau ingkar janji atau tidak menyelesaikan kewajibanya sesuai dengan perjanjian baik jumlah maupun waktu, misalnya pembayaran atas perhitungan bunga maupun utang pokok. ${ }^{5}$

Kredit bermasalah dapat disebabkan oleh beberapa faktor, yakni adanya faktor internal dan faktor eksternal. ${ }^{6}$

\footnotetext{
${ }^{5}$ Mantayborbir, et.all, Hukum Piutang dan Lelang Negara di Indonesia", Pustaka Bangsa, Medan, 2002, hlm.23.

${ }^{6}$ Sumber Data dari PT. Kreditor Mandiri RCR 1 Medan, tanggal 02 Februari 2011, hal.3.
}

Faktor internal yang menjadi penyebab timbulnya kredit bermasalah yaitu:

a. Kebijakan perkreditan yang ekspansif.

b. Penyimpangan dalam pelaksanaan prosedur perkreditan.

c. Itikad kurang baik dari pemilik, pengurus atau pegawai kreditor.

d. Lemahnya sistem administrasi dan pengawasan kredit serta lemahnya sistem informasi kredit bermasalah.

Faktor eksternal penyebab timbulnya kredit bermasalah adalah:

a. Kegagalan usaha debitor.

b. Musibah terhadap debitor atau terhadap kegiatan usaha debitor.

c. Pemanfaatan iklim persaingan perbankan yang tidak sehat oleh debitor.

d. Menurunnya kegiatan ekonomi dan tingginya suku bunga kredit.

Kredit bermasalah dalam perspektif KUHPerdata adalah semua subjek hukum baik manusia atau badan hukum dapat membuat suatu persetujuan yang menimbulkan perikatan di antara pihakpihak yang mengikat bagi para pihak yang melakukan perjanjian tersebut sebagaimana yang diatur dalam Pasal 1338 KUH Perdata.Di dalam perjanjian selalu ada dua subjek, yaitu pihak yang berkewajiban melakukan suatu prestasi dan pihak yang berhak atas suatu prestasi. Di dalam pemenuhan suatu prestasi atas perjanjian yang telah dibuat oleh para pihak tidak jarang pula debitor (nasabah) lalai melaksanakan kewajibannya atau tidak melaksanakan suatu prestasi, hal inilah yang disebut keadaan wanprestasi. Perkataan "wanprestasi" berasal dari Bahasa Belanda yang berarti: "prestasi yang buruk" dan bila dibandingkan dengan perkataan Wanbeheer yang berarti pengurusan yang buruk, demikikan juga 
dengan perkataan "Wanddad", yang berarti perbuatan buruk.

Pengertian mengenai wanprestasi belum mendapat keseragaman, masih terdapat bermacam-macam istilah yang dipakai untuk wanprestasi, sehingga tidak terdapat kata sepakat untuk menetukan istilah mana yang hendak dipergunakan. Istilah mengenai wanprestasi ini terdapat beberapa istilah, yaitu: ingkar janji, cidera janji, melanggar janji, dan lain sebagainya.

Dengan adanya bermacam-macam istilah mengenai wanprestasi ini, telah menimbulkan kesimpangsiuran dengan maksud aslinya, yaitu wanprestasi. Ada beberapa sarjana yang tetap menggunakan istilah "wanprestasi" dan memberi pendapat tentang pengertian mengenai wanprestasi tersebut.

Prof. Subekti mengemukakan ${ }^{7}$,bahwa "wanprestasi" adalah kelalaian atau kealpaan yang dapat berupa empat macam, yaitu:

a. Tidak melakukan apa yang telah disanggupi akan dilakukannya

b. Melaksanakan apa yang telah diperjanjikannya, tetapi tidak sebagaimana yang diperjanjikan

c. Melakukan apa yang diperjanjikan tetapi terlambat.

d. Melakukan sesuatu perbuatan yang menurut perjanjian tidak dapat dilakukan.

Untuk mengatasi kredit bermasalah, pihak Bank perlu melakukan penyelamatan untuk mencegah kerugian yang lebih besar. Menurut Peraturan Bank Indonesia Nomor 13/26/PBI/2011 Pasal 9 tentang penyelamatan kredit bermasalah dapat dilakukan diantaranya sebagai berikut:

7 R. Subekti, "Hukum Perjanjian", Cet. Ke-II Pembimbing Masa, Jakarta, 1970, hlm.50.
1) Rescheduling (Penjadwalan

Kembali)ialah upaya penyelamatan kredit dengan melakukan perubahan syarat-syarat perjanjian kredit yang berkenaan dengan jadwal pembayaran kembali kredit atau jangka waktu, termasuk grace period baik termasuk besarnya jumlah angsuran maupun tidak.

2) Reconditioning(Persyaratan Kembali)ialah upaya penyelamatan dengan cara melakukan perubahan atas sebagian atau seluruh syarat perjanjian kredit yang tidak terbatas hanya kepada perubahan jadwal angsuran atau jangka waktu kredit saja, namun perubahan tersebut tanpa memberikan tambahan kredit atau tanpa melakukan konversi atas seluruh atau sebagian dari kredit menjadi equity perusahaan.

3) Restructuring (Penataan Kembali) ialah upaya penyelamatan dengan melakukan perubahan syarat-syarat perjanjian kredit berupa pemberian tambahan kredit atau melakukan konversi atas seluruh atau sebagian dari kredit menjadi equity perusahaan dan equity bank, yang dilakukan dengan atau tanpa rescheduling atau reconditioning.

Penyelesaian kredit bermasalah dapat dilakukan sesuai Undang-Undang No. 30 tahun 1999 tentang Arbitrase dan Altenatif Penyelesaian Sengketa melalui cara konsultasi, negoisasi maupun mediasi.

Penyebab terjadinya kredit bermasalah di PT. BPR Weleri Makmur Cabang Kudus ada 2 faktor yaitu faktor internal Bank dan faktor eksternal Bank. Faktor internal yang menyebabkan kredit bermasalah adalah:

1. Adanya tindakan fraud oleh karyawan 
Fraud mempunyai arti kecurangan atau kebohongan yang dilakukan untuk kepentingan pribadi yang dapat merugikan orang lain.Menurut Karyono definisi fraud adalah $^{8}$ : "Fraud dapat diistilahkan sebagai kecurangan yang mengandung makna suatu penyimpangan dan perbuatan melanggar hukum (illegal act), yang dilakukan dengan sengaja untuk tujuan tertentu misalnya menipu atau memberikan gambaran keliru (mislead) kepada pihak-pihak lain, yang dilakukan oleh orang-orang baik dari dalam maupun dari luar organisasi. Kecurangan di rancang untuk memanfaatkan peluang-peluang secara tidak jujur, yang secara langsung maupun tidak langsung merugikan pihak lain.”

Tindakan fraudyang dilakukan karyawan yang menyebabkan kredit bermasalah adalah:

a. Memakai uang angsuran nasabah untuk kepentingan pribadi.

b. Meminta uang kepada nasabah.

c. Melakukan persengkokolan dengan nasabah.

2. Adanya pelanggaran prinsip kehatihatian dalam pemberian kredit

Prinsip kehati-hatian dalam pemberian kredit telah diatur dalam Undang-Undang Nomor 10 Tahun 1998 TentangPerubahan atas UndangUndang Nomor 7 Tahun 1992 Tentang Perbankan Pasal 29 angka-angka sebagai berikut: "Bank wajib memelihara tingkat kesehatan Bank sesuai dengan ketentuan kecukupan modal, kualitas aset, kualitas manajemen, likuiditas, rentabilitas,

8 Karyono, 'Forensic Fraud", $\quad$ CV. Andi, Yogyakarta, 2013, hlm.4-5. solvabilitas, dan aspek lain yang berhubungan dengan usaha Bank, dan wajib melakukan kegiatan usaha sesuai dengan prinsip kehati-hatian'.

Contoh pelanggaran prinsip kehati-hatian dalam pemberian kredit pada PT. BPR Weleri Makmur Cabang Kudus adalah:

a. Rekayasa data nasabah.

b. Tidak melakukan survey ke nasabah.

c. Melakukan survey tanpa cek lingkungan.

d. Terlalu percaya kepada nasabah.

Sedangkan faktor eksternal penyebab kredit bermasalah adalah:

1. Kondisi perekonomian dan Kebijakan politik yang sering berubah-ubah contohnya, kenaikan harga BBM, kenaikan bea cukai dll.

2. Adanya bencana contohnya, adanya musibah banjir besar, adanya gunung meletus dll.

3. Faktor debitor contohnya, adanya itikad kurang baik dari debitor, adanya penyimpangan penggunaan dana kredit, pola hidup yang boros, dan adanya kegagalan usaha dari debitor.

Dari semua faktor-faktor diatas yang menyebabkan kredit bermasalah diperlukan penyelesaian yang cepat agar tidak menjadi berlarut-larut sehingga akan membebani tingkat kesehatan bank tersebut. Dalam penyelesaian suatu perbuatan hukum, dapat ditempuh melalui dua jalan yaitu dengan jalan litigasi dan non litigasi. Penyelesaian melalui jalur litigasi atau sering kita ketahui dengan melakukan suatu mekanisme peradilan, kita dapat ajukan dua hal yaitu tindakan perdata maupun pidana.

Pengajuan perkara perdata melalui Peradilan mempunyai segi positif dan negatif, dari segi positif, apabila kita 
menang maka ada kekuatan hukum yang mengikat yang harus segera dilaksanakan, tetapi dari segi negatifnya hasil yang akan dicapai nantinya bisa tidak sesuai dengan apa yang kita inginkan. Maka ada semboyan apabila kita berperkara perdata yaitu menang jadi arang dan yang kalah jadi abu, ini berarti bahwa menang atau kalah dalam hal keperdataan membawa akibat yang sama-sama kurang baik.

PT. BPR WM Cabang Kudus di dalam menyelesaikan suatu perkara keperdataan selalu menggunakan jalur non litigasi atau di luar pengadilan terlebih dahulu sebelum melakukan penyelesaian melalui jalur litigasi. Hal ini dikarenakan penyelesaian kredit bermasalah melalui jalur non litigasi lebih menguntungkan bagi debitor maupun kreditor. Penyelesaian kredit bermasalah melalui jalur non litigasi adalah penyelesaian yang saling menguntungkan (win-win solution) langkah-langkah untuk mencapai penyelesaian kredit bermasalah dengan cara yang saling menguntungkan demikian dapat dicapai melalui cara sesuai dengan Undang-Undang No 30 tahun 1999 tentang penyelesaian sengketa dengan cara konsultasi, negoisasi, mediasi. Langkah ini dapat dilakukan apabila para pihak mendasarkan pada itikad baik.

Penyelesaian kasus kredit bermasalah yang dilakukan oleh PT. BPR WM dengan jalan di luar pengadilan mempunyai beberapa tahapan diantaranya sebagai berikut:

1. Pemberian Surat Peringatan

2. Pemberian Surat Panggilan

Tahapan inilah biasanya tercapai kesepakatan antara PT. BPR WM dengan debitor dalam menyelesaikan kasus kredit bermasalah. Cara yang dilakukan dalam penyelesaian kasus kredit bermasalah pada PT. BPR WM sesuai dengan Undang-Undang No. 30 tahun 1999 tentang penyelesaian sengketa diantaranya dengan cara konsultasi, negosiasi dan mediasi. Contoh beberapa kasus kredit bermasalah yang diselesaiakan secara konsultasi, negoisasi dan mediasi sebagai berikut:

a. Konsultasi

Konsultasi yang dilakukan debitor bermasalah kepada PT. BPR WM merupakan sikap atau tindakan yang menunjukkan masih ada itikad baik dari debitor dalam menyelesaikan permasalahan yang terjadi. Tahapan ini biasanya debitor menceritakan penyebab terjadinya keterlambatan pembayaran yang menjadikan kreditnya bermasalah. PT. BPR WM akanmencarikan solusi yang terbaik kepada debitor dengan menawarkan 3Ryaitu, Rescheduling(penjadwalan

kembali), Reconditioning (persyaratan kembali) dan Restructuring (penataan kembali).

b. Negosiasi

Negosiasi merupakan langkah yang baik yang dilakukan oleh debitor untuk segera menyelesaikan kredit bermasalah yang dialami dengan cara melakukan penawaran pelunasan kredit untuk mendapatkan keringanan pelunasan.

c. Mediasi

Langkah mediasi juga dilakukan oleh debitor melalui pihak ketiga dalam menyelesaiakan kredit bermasalah yang dialami agar cepat segera terselesaikan.

3. Surat Pemberitahuan Rencana Lelang.

4. Eksekusi Lelang. 
Pertimbangan mengapa PT. BPR WM Cabang Kudus lebih memilih jalur non litigasi dari pada jalur litigasi, pertimbangan tersebut berdasarkan uraian di atas diantaranya berkaitan dengan masalah biaya, waktu, hasil yang dicapai dan adanya itikad baik debitor.

\section{Kesimpulan}

Penyebab terjadinya kredit bermasalah di PT. BPR Weleri Makmur Cabang Kudus terdapat 2 faktor yaitu faktor internal dan faktor eksternal Bank.

Penyebab kredit bermasalah pada internal Bank yaitu, adanya tindakan fraud dari karyawan dan adanya pelanggaran prinsip kehati-hatian dalam pemberian kredit.

Faktor eksternal Bank yang menyebabkan kredit bermasalah diantaranya yaitu, kondisi perekonomian dan kebijakan politik yang sering berubahubah, adanya bencana alam dan adanya faktor debitor.

Penyelesaian kredit bermasalah di luar pengadilan dijadikan alternatif yang lebih diutamakan di BPR WM karena adanya masalah biaya, hasil yang dicapai, itikad baik debitor, serta kemampuan membayar debitor.

\section{Saran}

1. Masyarakat yang mempunyai kredit diharapkan untuk melakukan kewajiban pembayaran angsuran dengan baik agar tidak bermasalah dengan pihak Bank.

2. Bank harus lebih tegas kepada karyawan yang melakukan tindakan fraud serta lebih berhati-hati dalam memberikan kredit kepada nasabah..

3. Terhadap pemerintah diharapkan jangan terlalu melakukan perubahan kebijakan politik dan ekonomi.

\section{DAFTAR PUSTAKA}

Budi Untung, 2000, Kredit Perbankan Indonesia, Penerbit Andi, Yogyakarta.

Kasmir, 2008, Bank dan Lembaga Keuangan Lainya, PT. Rajagrafindo Persada, Jakarta.

R. Subekti, 1979, Hukum Perjanjian, PT. Intermasa, Jakarta.

S. Mantayborbir, et al, 2002, Hukum Piutang dan Lelang Negara di Indonesia, Pustaka Bangsa, Medan.

Thomas Suyatno, 1997, Kelembagaan Perbankan, Gramedia, Jakarta.

Karyono, 2013, Forensic Fraud, CV. Andi, Yogyakarta.

Safir Senduk,2014, Prospek Perbankan di Indonesia",www.kompasroom.com, April 2014. 
